\title{
PLANT-AND-SOIL ZONATION IN THE SURROUNDINGS OF THE AJINOUR SALT LAKE IN NW AZERBAIJAN
}

\section{INTRODUCTION}

The interrelations between soil and vegetation have since long been an interesting research issue, considered across a broad spatial scale, ranging from the global models (see, e.g., Knorr et al., 1995) down to the detailed analyses of differentiation within the individual ecosystems (e.g. Cross, Schlesinger, 1999). Of special interest are the interrelations observed at the level of landscape, under the circumstances of sharply delineated habitat gradients.

The work here presented belongs exactly to this stream of research. The purpose of the report is to show the general outline of differentiation of the soil conditions and the vegetation cover within the closest vicinity of the Ajinour lake in Azerbaijan (47 $00^{\prime} 21^{\prime \prime} \mathrm{E}$ and $\left.41^{\circ} 1^{\prime} \mathrm{N}\right)$.

\section{GENERAL CHARACTERISATION OF THE AJINOUR LAKE AND THE SURROUNDING AREAS}

Ajinour lake is located at the elevation of approximately $107 \mathrm{~m}$ a.s.l. in the western part of the Kuran Plain. It occupies the bottom of a vast intermontane low having roughly NW-SE orientation. The plain that surrounds the lake is closed on the North by the Amviran ridge, and on the side of the Kura river and the Mingechauri reservoir - by the Kadjashen' ridge. Both these ridges attain the elevation of 350-700 $\mathrm{m}$ a.s.l., and are cut through by a dense network of dry valleys and gullies. The Kadjashen' ridge is overgrown by the dry mountain steppe associations, while the slopes of the Amviran ridge, turned towards the lake, are dominated by the naked, strongly eroded surfaces, the "badlands".

The ridges, forming the borders of the Ajinour plain, are primarily built of the Pliocene sandy and clayey sediments, while their piedmonts - of the Pleistocene marine, salty loams (to the North of the lake), and the continental alluvial-lacustrine, as well as deluvial material. The bottom of the valley, with the lake, is covered by the late-Pleistocene and Holocene fine-grained sands, dusts and loams, to the thickness of 3-40 metres. Except for the direct neighbourhood of the lake, there is virtually no groundwater in this area. 
Ajinour lake has no surface outflow. It is supplied with water seasonally, mainly during spring, and, after intensive rains, by the seasonal flow of Dakhna-chai, as well as by the canal releasing water from the irrigation systems. In the dry periods the surface of the lake is at about $15 \mathrm{sq} . \mathrm{km}$, while in the early spring it reaches approximately $30 \mathrm{sq} . \mathrm{km}$. In the latter period the lake attains the length of some $10 \mathrm{~km}$ with the average depth of roughly 1 metre. The maximum depth of $2.5-3.0 \mathrm{~m}$ persists in the eastern part of the lake. The outline of the ancient shoreline, visible clearly, in particular, on the aerial photography, allows to judge that yet a couple of hundred years ago the lake could have been several times bigger than today. Water of the Ajinour lake is salty. The sources of the easily dissolved salts are constituted both by the deluvial material brought from the surrounding areas, and by the waters of the seasonal inflows supplying the lake.

The origin of the lake has not been unambiguously determined until now. It is assumed that it is a lagoon lake, a remnant of the Tertiary (?) transgression of the Caspian Sea. The chemical composition of the two water bodies might indicate a far relation between the waters of Ajinour lake and those of the Caspian Sea (see Table 1). In both cases chlorine ions dominate. They

Table 1.

Chemical composition of water from Ajinour lake and the Caspian Sea

\begin{tabular}{|l|c|c|c|c|c|c|c|c|}
\hline Ions & $\mathrm{Ca}^{2+}$ & $\mathrm{Mg}^{2+}$ & $\mathrm{Na}^{+}$ & $\mathrm{HCO}_{3}^{-}$ & $\mathrm{Cl}^{-}$ & $\mathrm{SO}_{4}^{-2}$ & Total \\
\cline { 2 - 9 } & \multicolumn{6}{|c|}{$\mathrm{Meq} / \mathrm{kg}$} \\
\hline $\begin{array}{l}\text { Sample of ofigin water } \\
\text { Ajinour lake, eastern part } \\
\text { (Ismailov, 1985) }\end{array}$ & 51.1 & 23.3 & 607.2 & 2.4 & 511.2 & 168.0 & 44.03 \\
\hline $\begin{array}{l}\text { Caspian Sea (Fizikogeo- } \\
\text { graficheskiy_.., 1964) }\end{array}$ & 17.0 & 62.6 & 129.2 & 3.5 & 143.3 & 62.0 & 12.73 \\
\hline
\end{tabular}

constitute approximately $75 \%$ of all anions in the water from Ajinour lake, and approximately $68 \%$ in the Caspian Sea water. The shares of the sulphate ions are, respectively, $24.6 \%$ and $29.7 \%$, while the ratio $\mathrm{Cl}^{-} / \mathrm{SO}_{4}{ }^{-2}$ equals, respectively, 3.0 and 2.3. More significant differences are observed with respect to the cations. Thus, water of the Ajinour lake indicates a very high concentration of the sodium ions, while it lost an enormous amount of magnesium in comparison with the water of the Caspian Sea. The original "Caspian" magnesium-sodium water turned in this situation into the sodium water. The contents in calcium ions increased as well. It is admitted (Glazovskaya, 1988), that the transformation of the chemical composition in the water of the sea-coast lakes is connected with the processes of exchange of the calcium bicarbonate supplied from the inland and the magnesium sulphate, contained in the seawater. Consequently, precipitation of dolomite and gypsum 
takes place. In case of disappearance of sulphate ions calcium chloride might appear in the solution:

$$
\begin{aligned}
& 2 \mathrm{Ca}\left(\mathrm{HCO}_{3}\right)_{2}+\mathrm{MgSO}_{4}=\mathrm{CaMg}\left(\mathrm{CO}_{3}\right)_{2}+\mathrm{CaSO}_{4}+2 \mathrm{CO}_{2}+\mathrm{H}_{2} \mathrm{O} \\
& 2 \mathrm{Ca}\left(\mathrm{HCO}_{3}\right)_{2}+\mathrm{MgCl}_{2}=\mathrm{CaMg}\left(\mathrm{CO}_{3}\right)_{2}+\mathrm{CaCl}_{2}+2 \mathrm{CO}_{2}+\mathrm{H}_{2} \mathrm{O}
\end{aligned}
$$

A part of magnesium ions are also persistently fixed in the loam minerals, the products of the weathering process synthesis. The concentration of the main ions in the water of Ajinour lake at the end of Summer would amount in the eastern part to $45 \mathrm{~g} /$ litre, and in the shallow, western part - to $85 \mathrm{~g} / \mathrm{litre}$.

\section{THE SOIL AND VEGETATION DIFFERENTIATION}

\section{Basin borders}

Soils typical for the climate of dry steppes and semi-deserts appear in the surroundings of the Ajinour lake. Summers are hot and dry here, while winters mild. The average annual air temperature equals $14-15^{\circ} \mathrm{C}$, average temperature of July is around $25^{\circ} \mathrm{C}$, and of January - roughly $1^{\circ} \mathrm{C}$. The annual precipitation (with the maximum in spring) is at $300-350 \mathrm{~mm}$, and it balances the potential evaporation in only $30 \%$. In such hydrothermal and geomorphological conditions of the surroundings of the Ajinour lake various kinds of salinised soils, and the plant associations linked with them, develop. On the other hand, along the fringe of the low, the proper mountain chestnut soils of the dry, mainly absinthine steppes, appear, while in the southern part, adjacent to the Mingechauri reservoir, the grey earths do. These soils, having developed on the clays and loams, containing - side by side with the calcium carbonates, also gypsum precipitations, and, locally - to the $\mathrm{SE}$ and NW of the lake - also chlorides, are subject to a strong and moderate, mainly hydrogenic, erosion. The products of destruction of these soils partly reach the lake as deluvia.

\section{Areas of very fine sandy and silty sediments of the peri-lacustrine plain}

On the plain adjacent to the lake the areas of higher elevation are built of the very fine deluvial sand and silt-and-clay sediments, displaying a variety of degrees of salinisation, as well as a differing composition of the easily soluble salts. These surfaces are not flooded nowadays by the lake, while the soils that cover them feature automorphous salinisation. The complexes of the solonchak chestnut soils and the proper solonchaks developed here (Table 2, profiles 8 and 9). These soils contain in the humus layers $2.5-4.8 \%$ of the easily soluble salts, and at the levels of the matrix rock $-3.3-8.6 \%$ of them. The composition of the salts varies within the soil profile. In the upper layers the chloride and the sulphate-chloride type of salinisation persists, while in the deeper layers - the sulphate-chloride and sulphate type. It is only here (profile no. 9) that the soil levels are encountered with a significant accumulation of magnesium. The soils displaying a high share 
Contents of the easily dissoluble salts in the soils of the vicinity of the Ajinour lake

\begin{tabular}{|c|c|c|c|c|c|c|c|}
\hline \multirow{2}{*}{ Sample origin } & $\mathrm{Ca}^{2+}$ & $\mathrm{Mg}^{2+}$ & $\mathrm{Na}^{+}$ & $\mathrm{HCO}_{3}{ }^{-}$ & $\mathrm{Cl}^{-}$ & $\mathrm{SO}_{4}{ }^{-2}$ & \multirow{3}{*}{$\begin{array}{l}\text { Total } \\
\text { g/100g }\end{array}$} \\
\hline & \multicolumn{6}{|c|}{ Meq/100 g of soil } & \\
\hline \multicolumn{7}{|l|}{ Soil profile no. 4} & \\
\hline $0.3-3.5 \mathrm{~cm}$ & 30.5 & 3.0 & 177.8 & 12.0 & 141.8 & 57.5 & 13.26 \\
\hline $25-35 \mathrm{~cm}$ & 10.7 & 1.6 & 37.4 & 12.0 & 30.0 & 7.0 & 3.23 \\
\hline $70-80 \mathrm{~cm}$ & 4.6 & 2.0 & 37.3 & 8.0 & 14.0 & 21.0 & 2.97 \\
\hline $120-130 \mathrm{~cm}$ & 12.2 & 1.7 & 46.7 & 6.0 & 43.9 & 10.0 & 3.74 \\
\hline \multicolumn{8}{|l|}{ Soil profile no. 6} \\
\hline $0-11 \mathrm{~cm}$ & 4.6 & 0.7 & 21.1 & 10.0 & 12.0 & 4.1 & 1.82 \\
\hline $35-60 \mathrm{~cm}$ & 15.2 & 0.9 & 17.7 & 8.0 & 18.0 & 7.3 & 2.20 \\
\hline $80-85 \mathrm{~cm}$ & 17.7 & 1.5 & 40.5 & 10.0 & 30.0 & 18.7 & 3.86 \\
\hline \multicolumn{8}{|l|}{ Soil profile no. 8} \\
\hline $8-12 \mathrm{~cm}$ & 9.1 & 1.7 & 27.4 & 10.0 & 22.0 & 5.4 & 2.48 \\
\hline $40-50 \mathrm{~cm}$ & 4.6 & 1.2 & 30.3 & 8.0 & 22.0 & 5.6 & 2.34 \\
\hline $85-95 \mathrm{~cm}$ & 15.2 & 1.6 & 34.8 & 8.0 & 24.0 & 18.8 & 3.36 \\
\hline \multicolumn{8}{|l|}{ Soil profile no. 9} \\
\hline $0-10 \mathrm{~cm}$ & 18.3 & 3.0 & 53.5 & 10.0 & 39.9 & 24.9 & 4.86 \\
\hline $40-50 \mathrm{~cm}$ & 47.2 & 6.1 & 57.1 & 8.0 & 32.0 & 70.4 & 7.33 \\
\hline $90-100 \mathrm{~cm}$ & 88.3 & 10.6 & 28.1 & 8.0 & 12.0 & 107.6 & 8.63 \\
\hline
\end{tabular}

of the sulphate ions across the entire profile (including, of course, gypsum), are being partly used as arable lands.

Under such habitat-related circumstances two types of plant associations appear, linked by numerous intermediate stages. The first of these is the steppe with the domination of Artemisia fragrans (Table 3), where an important role is played by the halophytes from the Chenopodiaceae family (like Kalidium caspicum and Salsola nodulosa). The weight of the fresh biomass is here among the highest, attaining even more than $550 \mathrm{~g}$ per sq. $\mathrm{m}$, though approximately $50 \%$ of surface remains without the vegetation cover.

The second type mentioned encompasses the desert steppes with domination of the Aeluropus litoralis grass and a high share of Artemisia fragrans (Table 3). In places used as pastures the weight of the fresh phytomass is at $250-320 \mathrm{~g}$ per sq. $\mathrm{m}$, while around $30 \%$ of surface remains without the vegetation cover.

Both these types of associations are mainly composed of the perennial species, characterised by the leaves of the xeromorphic type.

\section{Areas shortly flooded}

The solonchaks developing on the areas, which are flooded for the short periods of time (Table 2, profile no. 6), are subject to weak erosion. The short- 
Table 3.

The species composition (cover in \%) of the plant associations around the Ajinour lake

\begin{tabular}{|c|c|c|c|c|c|c|c|c|c|c|c|c|c|}
\hline the unit on the Fig. 1 & $\mathrm{~h}$ & $\mathrm{~h}$ & $d$ & $d$ & $\mathrm{f}$ & $\mathrm{f}$ & $\mathrm{e}$ & $\mathrm{e}$ & $\mathrm{e}$ & $\mathrm{e}$ & $\mathrm{c}$ & $\mathrm{g}$ & $\mathrm{g}$ \\
\hline $\begin{array}{l}\text { description area } \\
\text { (sq. m) }\end{array}$ & 40 & 40 & 100 & 100 & 100 & 100 & 100 & 100 & 100 & 100 & 100 & 100 & 100 \\
\hline $\begin{array}{l}\text { fresh phytomass } \\
(\mathrm{g} / \mathrm{sq} . \mathrm{m})\end{array}$ & 58,7 & 74,2 & 673 & 1902 & 343 & 400 & 343 & 570 & 394 & 1576 & 561 & 249 & 327 \\
\hline $\begin{array}{l}\text { Total plant cover } \\
(\%)\end{array}$ & 8 & 40 & 40 & 70 & 70 & 65 & 80 & 90 & 90 & 70 & 55 & 70 & 65 \\
\hline Dominant species & & & & & & & & & & & & & \\
\hline $\begin{array}{l}\text { Salicornia } \\
\quad \text { herbacea s.l. }\end{array}$ & 8 & 15 & 1 & & & & & & & & & & \\
\hline $\begin{array}{l}\text { Halocnemum } \\
\text { strobilaceum }\end{array}$ & & 10 & 40 & 40 & 1 & & & & & & & 1 & \\
\hline $\begin{array}{r}\text { Petrosimonia } \\
\text { branchiata }\end{array}$ & & 1 & 1 & 30 & 60 & 50 & 40 & 40 & 40 & & & 5 & 1 \\
\hline Kalidium caspicum & & & & & & & 10 & 20 & 40 & 30 & 1 & & \\
\hline Salsola nodulosa & & & & & & & 20 & 10 & 5 & 10 & 25 & & \\
\hline Artemisia fragrans & & & & & 5 & 1 & 1 & 5 & & 30 & 30 & 30 & 5 \\
\hline Aeluropus litoralis & & 15 & & & 5 & 10 & 1 & 5 & 1 & & & 30 & 60 \\
\hline Other species & & & & & & & & & & & & & \\
\hline Limonium meyeri & & 1 & 1 & 1 & 1 & & 1 & 5 & 1 & 1 & 1 & 1 & \\
\hline Colpodium humile & & & & & 1 & 1 & 1 & 5 & 1 & 1 & & 1 & 3 \\
\hline $\begin{array}{l}\text { Halimocnemis } \\
\text { sclerosperma }\end{array}$ & & & & & 1 & 5 & & & & & & 5 & \\
\hline Anabasis aphylla & & & & & & & 10 & & 1 & & & & \\
\hline Salsola cfr. nitraria & & & & & 1 & & & & & & & & 1 \\
\hline $\begin{array}{l}\text { Echinopsilon } \\
\text { hyssopifolium }\end{array}$ & & & & & & & & 5 & & & & & \\
\hline Salsola glauca & & & & 5 & & & & & & & & & \\
\hline Trachynia distachya & & & & & & & & & & & 1 & & \\
\hline
\end{tabular}

lived spring floods and the surface flow of the precipitation water in the direction of the lake are conducive to the desalinisation of the upper layers of the soil. In the humus layers the chlorine ions dominate only insignificantly over the bicarbonate ions. These layers are at the same time very poorly salinised - only $1.8 \%$ of the easily soluble salts appear here, while at the level of the matrix rock - approximately $3.8 \%$. Three types of clearly halophyte associations developed in these conditions. The first of these types is dominated by the annual species of Petrosimonia branchiata, covering approximately $60 \%$ of the soil surface (Table 3). Here also, large, though isolated tufts are encountered of the grass Aeluropus litoralis, a perennial herb excreting salt, and cumulating, in particular, a lot of silicae $\left(\mathrm{SiO}_{2}\right.$ constitutes around $65 \%$ of the ash), as well as potassium and sulphur (Walter, 1968). 
The weight of the fresh phytomass in this association, composed mainly of the taxa with sclerophylic leaves, amounts to $340-400 \mathrm{~g}$ per sq. m.

The second type of association distinguishes itself by a much higher share of the bushy species from the Chenopodiaceae family (Kalidium caspicum and Salsola nodulosa, see Table 3). The volume of fresh biomass ranges here between 340 and 570 g per sq. m.

The third type differs clearly from the two other ones. This association is a solonchak with the domination of the Halocnemum strobilaceum shrub (Table 3). It is here that the highest production of the fresh phytomass is observed, attaining approximately $1900 \mathrm{~g}$ per sq. m. The dry mass of this plant is composed in $30 \%$ of the mineral (ash) parts. It appears that this type of association is clearly close, in terms of habitat characteristics, to the subsequent group.

\section{The areas of the limic plain flooded annually and for longer periods}

Along the fringe of the limic plain, which is flooded every year and for longer periods of time, a narrow zone developed of the sore solonchaks, a hydrogenic kind of salinised soils, overgrown in principle by just three species of halophytes of differing persistence of growth. The dominant and the determinant of this zone is constituted by Salicornia herbacea, an annual pioneer species of the solonchaks, whose development is stimulated by the concentration of chlorine ions in the soil solution (Table 3). The dry mass of this plant contains some $33 \%$ of the ash part. Small and dispersed surfaces are occupied by the shrubs of Halocnemum strobilaceum, another halophyte settling the chloride solonchaks, and reaching with its roots the level of groundwater. The grass Aeluropus litoralis appears also here, with its sparsely distributed tufts attaining the diameter of approximately $200 \mathrm{~cm}$. Some $75 \mathrm{~g}$ of fresh phytomass grows here on every square metre. The tufts of all the three species mentioned occupy altogether approximately $40 \%$ of surface. A white and brittle shell of salt, having the thickness of $0.3-0.5 \mathrm{~cm}$, covers the soil between the tussocks. Below, down to the depth of some $4 \mathrm{~cm}$, a layered level appears, a steel-black, clammy loam with the algae, the rests of seaweed and roots. This thin cover, displaying the features of the "barrier of drying", contains approximately $13 \%$ of the easily dissoluble salts, including, side by side with the dominating sodium chloride, also increased amounts of calcium and magnesium. Very intensive processes of microbiological decomposition of the organic rests are taking place in this layer, using, in particular, the oxygen from a part of sulphates. These are the reduction processes, conducive to the formation of hydrosulphur and the colloidal iron sulphite - the hydrotroylite. The soil levels appearing below the hydrotroylite layer feature low humidity and practically do not display the symptoms of gleying.

At the end of summer the groundwater stabilises at the depth of around $0.9 \mathrm{~m}$. The easily dissoluble salts constituted approximately $3.7 \%$ of the sample taken from the depth of $125 \mathrm{~cm}$ (Table 2, profile no. 4). 


\section{The area of direct neighbourhood of the lake}

A surface covered with a thin white layer of salt and completely devoid of higher vegetation appears between the belt of the sore solonchaks with Salicornia herbacea and the permanent lake. In the summer, groundwater persists here at the depth of some $0.5 \mathrm{~m}$. Under the layer of seaweed cemented with the salt shell a wet, black hydrotroylite loam, smelling hydrosulphur, appears, and at the depth interval between 4 and $8 \mathrm{~cm}$ - a wet grey-green loam, weakly compact, with old, petty roots. The similarly strong symptoms of gleying persist practically down to the bottom of the soil profile. The soil below the hydrotroylite layer contains $3.7-4.9 \%$ of the easily dissoluble salts. In this "algae-and-seaweed" sore solonchak the primary importance must be assigned the processes stimulating in the seasons of flooding of the soil mainly the development of algae and seaweed, and in the periods of drying - their decomposition and reduction of the oxygen bonds. The intensity of the biochemical processes is most likely conditioned by the high temperatures of the soils, especially of the humid sore solonchaks.

In August 1984, after a couple of days of a cloudless weather, the temperature of the surface of the solonchak was at $43-44^{\circ} \mathrm{C}$, and of the hydrotroylite layer - at $36-39^{\circ} \mathrm{C}$. The thus intensive warming weakens the development

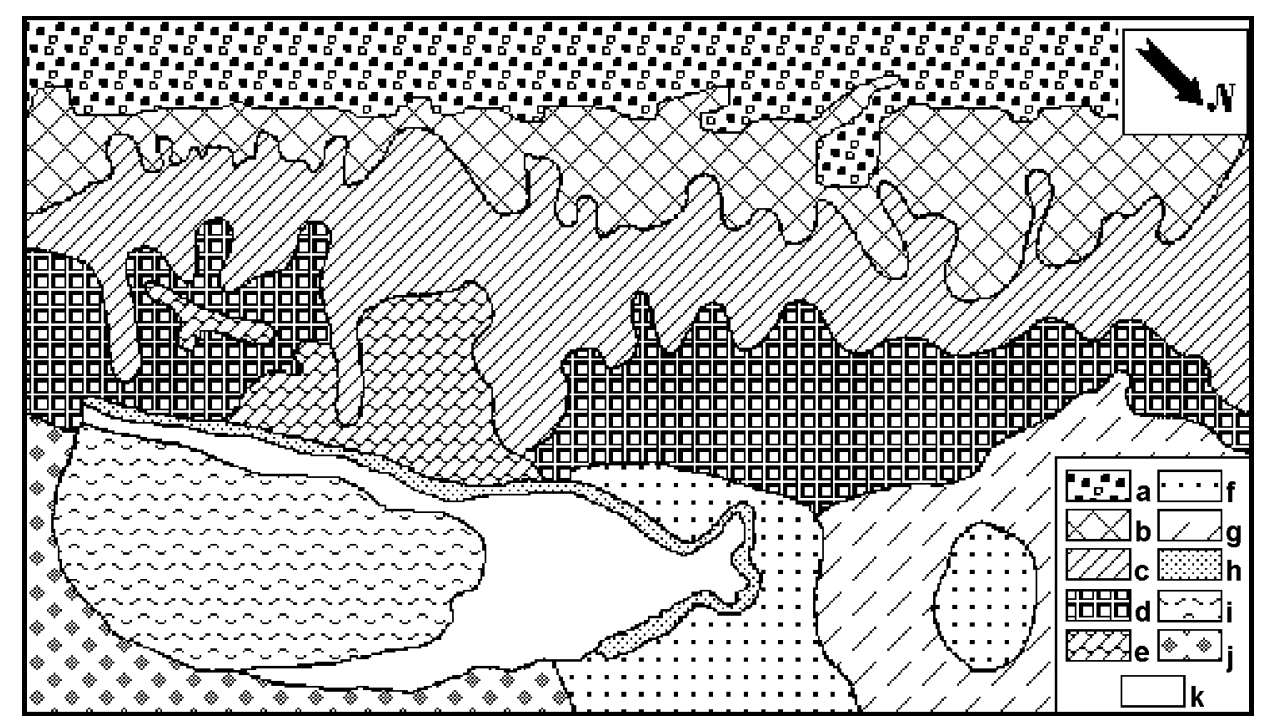

Fig. 1. Distribution of plant associations: a - vegetation of the heavily eroded rocky places; b - steppe on the very steep slopes; c - steppe with domination of Artemisia fragrans; $\mathrm{d}$ - solonchak with domination of Halocnemum strobilaceum (a perennial species); e - solonchak with domination of Kalidium caspicum and Salsola nodulosa (perennial taxa); f - solonchak with domination of Petrosimonia branchiata (an annual species); g - desert steppe with domination of the grasses; h - clusters of Salicornia herbacea; i - the lake; j - other associations, not considered in detail; $\mathrm{k}$ - areas devoid of higher plants. 


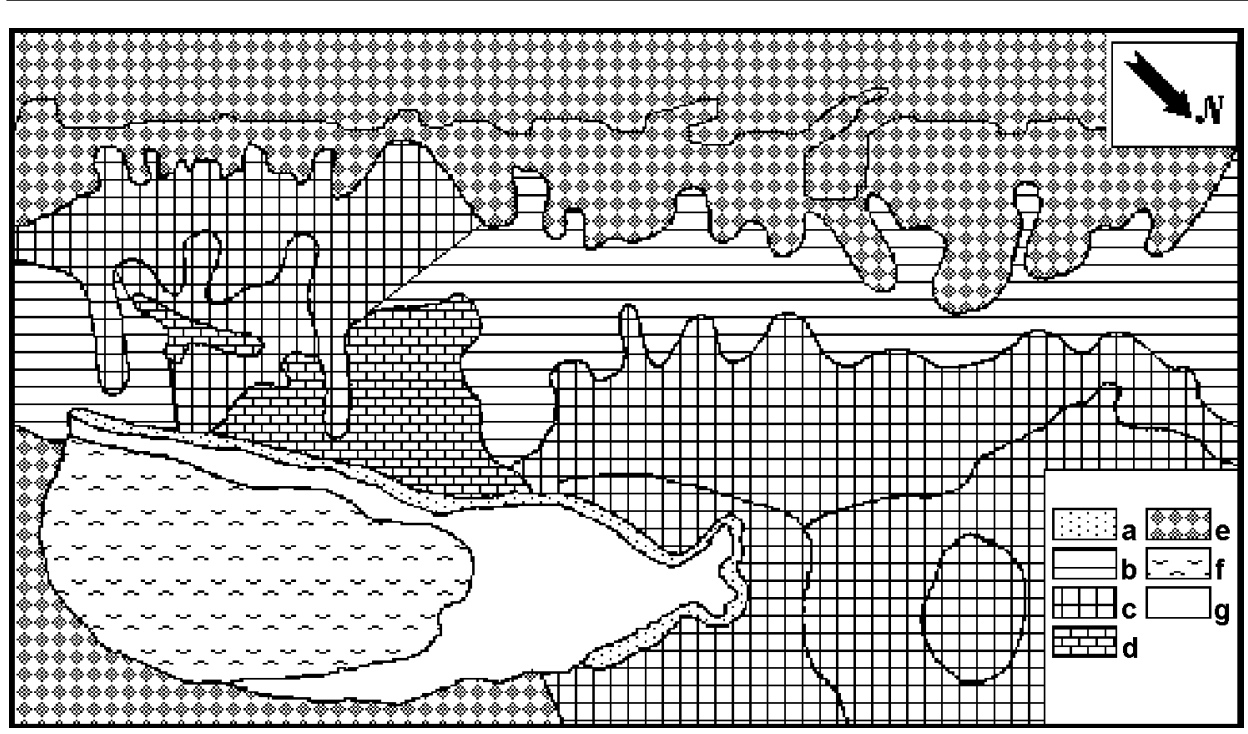

Fig. 2. Fresh biomass of the vascular plants (in g per sq. m): a $-<100 ; \mathrm{b}-250-400$; $\mathrm{c}-500-700 ; \mathrm{d}-1500-2000$; e - associations not analysed in detail; $\mathrm{f}-$ the lake; $\mathrm{g}-$ areas devoid of higher plants.

of roots of the majority of land plants. At the depth of $8-10 \mathrm{~cm}$ the temperature in both kinds of the sore solonchak was at $28-29^{\circ} \mathrm{C}$, and at the depth of $85 \mathrm{~cm}-$ at $25-27^{\circ} \mathrm{C}$. At the same time, the temperature of $23-25^{\circ} \mathrm{C}$ appeared in the profiles of the autonomous soils already at the depth of some $40 \mathrm{~cm}$.

\section{SUMMARY}

The soil-and-vegetation settings presented in the report constitute the examples of a distinct zoned character, determined first of all by the gradients of humidity and salinisation. In case of plant associations the zones appear primarily through the changes in the dominating species (Fig. 1), through the overall number of species, which is very low at the lake, increases in the halophyte associations, and then falls down again among the steppe associations, as well as through the role of the perennial species, whose share in the overall vegetation cover increases along with the distance from the lake.

Other features of the plant cover display, as well, the differentiation generally conform to the gradients of humidity and salinisation, though modified in their details by the local specificity (like the nature of the bedding). And so, for instance, the role of the species with the xeromorphic leaves increases most quickly in the NW direction away from the lake, while in the wettest places the species with the most succulent leaves dominate. A relatively regular setting is clearly disturbed in the case of distribution of the biomass 


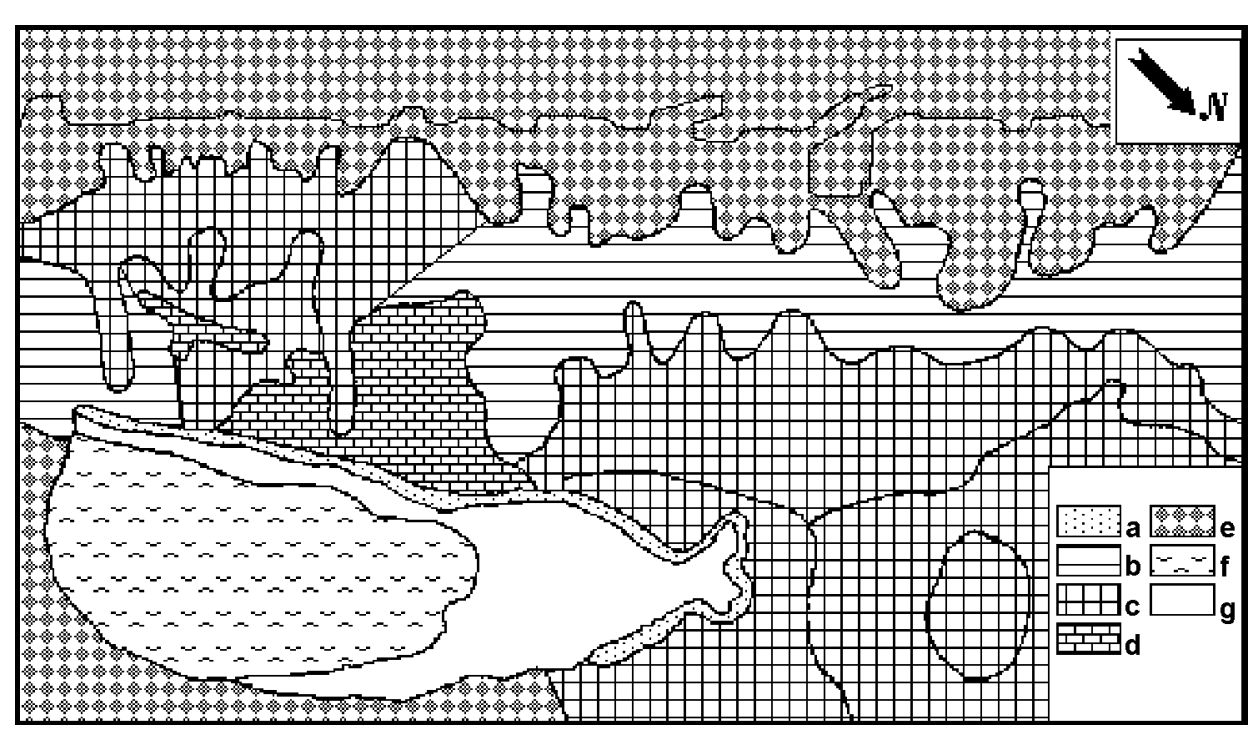

Fig. 3. Average vegetation cover (in \% of total surface): $\mathrm{a}-<10 ; \mathrm{b}-40-60 ; \mathrm{c}-60-80$; $\mathrm{d}->80$; e - associations not analysed in detail; $\mathrm{f}-$ the lake; $\mathrm{g}-$ areas devoid of higher plants.

resources (Fig. 2) and the covering of the land with vegetation (Fig. 3), which is primarily due to the anatomy and morphology of the dominating plant species.

The described above zonal differentiation of soils and vegetation, although slightly modified by the local factors, is of a general character. It is typical for extended areas, from the region of the Caspian Sea as far as almost to the western Mongolia.

\section{REFERENCES}

Cross A.F., Schlesinger W.H., 1999, Plant regulation of soil nutrient distribution in the northern Chihuahuan desert, Plant Ecology, 145 (1), 11-25.

Fizikogeograficheskiy Atlas Mira, 1964, [Physico-Geographical Atlas of the World; in Russian], Moskva.

Glazovskaya M.A.,1988, Geokhimiya prirodnykh i tekhnogennykh landshaftov SSSR [Geochemistry of the natural and technogenic landscapes of the USSR; in Russian], Vysshaya Shkola, Moskva.

Is m ailov V.K., (ed.), 1985, Albom pervichnykh dannykh mezhdunarodnogoaerokosmicheskogo eksperimenta "G'unesh" [Register of the original datafrom the international aero-spatial experiment "G'unesh"; in Russian], Baku.

Knorr W., Gobron N., Martin P., Pinty B., Verstraete M., Dedieu G., 1995, Constraining a climate-driven vegetation model with satellite data, [in:] Guyot G., (ed.), Photosynthesis and remote sensing. Proc. Colloquium. Montpellier, EARSeL, 269-279.

Walter H., 1968, Die Vegetation der Erde, Bd. II, VoB Gustav Fischer Verlag, Jena. 